\title{
Methods for Management of Fusarium Wilt in Tomato
}

\author{
Pothula Himabindu* and Vipul Kumar \\ Deportment of Plant Pathology, School of Agriculture, Lovely Professional University, \\ Phagwara (Punjab), India \\ *Corresponding author
}

\section{A B S T R A C T}

\begin{tabular}{l} 
Ke y w o r d s \\
$\begin{array}{l}\text { Soil born plant } \\
\text { pathogen, Host } \\
\text { pathogen } \\
\text { interaction, Control } \\
\text { methods }\end{array}$ \\
\hline Article Info \\
$\begin{array}{l}\text { Accepted: } \\
\text { 04 December } 2020 \\
\text { Available Online: } \\
\text { 10 January } 2021\end{array}$ \\
\hline
\end{tabular}

\section{Keywords}

Soil born plant pathogen, Host pathogen interaction, Control

\section{Introduction}

Tomato is the one of most important and popular commercial vegetable crop grown all over the world. It is excellent source in antioxidants and micronutrients. So it is suggested by nutrients and dieticians for controlling weight loss and cholesterol (Lenucci et al., 2006, Keswani, 2015). Tomato is also called as a nightshade which has around more than 300 species belongs to the family solanaceae. Brinjal, potato, tobacco and pepper are some of examples of solanaceae crops. Tomato is originated from Bolivia, Peru, Ecuador and chili. In 700 AD,
Tomato is a high esteem dietary component. Many factors are involved in low yield of tomato including the infestation by fungi, bacteria, virus, nematodes are mostly affected the crop. Among them Fusarium wilt seriously affected the tomato crop. Fusarium wilt is caused by Fusarium oxysporum which has reported to be most dangerous disease affecting a wide range of plants contains of weeds and ommercially domesticated plants and crop. Fusarium decreases the germination and seedling production. Integrated disease management (IDM) is the most costffective and environmental friendly strategy. Some essential controls are crop rotation, bio control and fungicide approaches used to handle these pathogens, and there is lack of knowledge on the relationship between management techniques and their effects on Fusarium ssp. None of the Fusarium wilt management techniques has demonstrated good outcomes.

tomato is first cultivated by Aztecs and Incas which is unclear. Portuguese explorers were introduced to India (Gomes et al., 2010). The major tomato production states in India Bihar, Karnataka, Uttar Pradesh, Orissa, Andhra Pradesh, Maharashtra, Madya Pradesh, and west Bengal. Tomato has greater coverage in comparison to other vegetables in all over India. It can adapt wide range climatic conditions. In summer season available best popular local tomatoes (Thamburaj and Singh, 2005). The tomato fruit consists well balanced nutrition contains minerals (calcium, iron, and phosphorus), vitamins (vitamin $-\mathrm{A}$, vitamin $\mathrm{C}$ ), sugars, essential amino acids, 
citric acid, etc. (Naika et al., 2005). In adding red pigment of lycopene has high anti oxidant ability against oxygen radicals that basically cause cancer, arteriosclerosis etc. (Giovannucci, 1999).

\section{Fusarium wilt}

Tomato has been attacked by the wide range of pathogens. In that soil and air born nature of pathogens cause economic loss in every year in terms of crop production and monetary loss to farmers (Gomes, 2010). Soil born disease causes major drawback of crop yielding. Rhizotonia ssp., Fusarium ssp., Verticillum ssp., Sclerotinia ssp., Pythium ssp., Phytophthora ssp., is some soil born diseases. These diseases can cause $50-75 \%$ yield loss in crop production (Lewis, J.A., Papavizas, 1991). In United States, soil born plant pathogens causes about $90 \%$ of the 2000 major diseases of the primary crop (BaysalGurel and Kabir, 2018). Fusarium is one of the most effecting fungal plant pathogen, which cause dangerous disease like Fusarium wilt and Fusarium root/stem (Charoenporn et al., 2010). The wilt of Fusarium is caused by Fusarium oxysporum poor of Fusarium solani. Vegetable crops are the majority of Fusarium solani hosts, but some strains may be infected by humans. In the world, more than 100 Fusarium vascular wilts are found (Burgess et al., 2008). This is global interest because about 32 countries have reported this disease, which is especially serious in countries about equator Fusarium wilt is caused by Fusarium oxysporum schlecht or Fusarium solani. Most of the hosts for Fusarium solani are vegetable crops but some strains may be infected to man. Across worldwide there are more than 100 Fusarium vascular wilts are present (Burgess et al., 2008). This is worldwide importance where around 32 countries reported about this disease, which is specifically severe in countries around equator Mui-Yun Wong,
(2003). The pathogen has a widely adapted under climate condition and it is a polyphagous nature if pathogen (Singh, 2014; Gill et al., 2016; Bhupendra et al., 2017). Consequently management of the disease very hard as well as single method is not adequate for managing of the disease. Mukhopadhyay (1987) initiate an integrated management of using cultural, biochemical, chemical treatments for managing of the disease (Bhatnagar et al., 2013; Minuto et al., 2000).

\section{Host pathogen interaction}

Fusarium oxysporum is one of the plant parasitic pathogen that interacts with the host plants it leads to development of Fusarium wilt infection. This fungus depends on plants growth and development then enters into the plant. the Fusarium oxysporum develop hyphae that attached as well as penetrate to the epidermal cells of both wounded and un wounded roots of plant the fungi also generate cell wall degradation enzymes like pectinase, cutinise and these enzymes are supports to penetration (Mendgen, Hahn and Holger deising). Once enters into the roots fungi occupy root cells and spread to all parts of plants with the help of water transpiration steam pull of water in the vascular tissues especially the xylem. The funguses produce micro and macro conidia while spreading to the vascular tissue.(Bishop and cooper). In the vascular tissue mycelial growth occurs it leads to blockage of the vessels thus results to water stress and formation of wilt symptoms. (Emiro, Ortiz et al., 2014)

\section{Symtoms of Fusarium oxysporum and disease development}

Fusarium wilt caused by soil-bearing fungus Fusarium oxysporum f.sp. previously, lycopersici was the most widespread and destructive field tomato disease. Symptoms usually begin in the plant, Fusarium 
oxysporum enters through the roots and hinders the water circulating though the plants vessels. As the fungus spreads to the roots and branches, it inhibit the flow of water, causing the foliage to wilt and becomes yellow.

The first symptom occurs on the lower (older) vine, as well as the disease spread by younger leaves, and the plants eventually die. In certain cases, only one branch or one side of the plant seems to have symptoms (Naika et al., 2005). Some cases stem remains hard and green on the outside and the infected do not die they turn into stunts and the yield is decreased. The browning of the vascular tissue and the reddish brown coloration of the xylem arteries can be seen as lines or spots throughout the stem. Pink fungal growth was seen the upper portion of the affected stems, especially in wet conditions (Burgess et al., 2008).

\section{Integrated disease management (IDM)}

Integrated disease control is an important tool for rising agriculture production and environmental destruction in developed countries (Waiganjo et al., 2006) this methods aims to maintain a safe soil, through the incorporation of organic matter, crop rotation the use of high residual tillage machinery (recycled organic unit, 2006) incorporation of green manure, and even cover crop rotation such as cabbage and cauliflower for least 4-5 years, especially basil based bio control agent, use of resistant cultivars, and the use of chemicals such as prochloraz and methyl bromide are some of the combined disease control method for Fusarium tomato wilt.(Ajilogba et al., 2013).

Integrated disease management is an effective method for increasing the agriculture production and environmental degradation for developing countries (Waiganjo et al., 2006). This practice helps to soil healthy including organic matter adding, crop rotation or using high residual tillage implements (Recycled Organics Unit, 2006).

Incorporation of green manure and also cover crops in a crop rotation it increases the fertility, induce the growth of the weeds and allow to disturbing the pest cycles (Jeff, 2009).

Crop rotation divergent crops such as cabbage and cauliflower for at least 4-5 years use especially bacillus based bio control agents, use of resistance cultivars, and use of chemicals like prochloraz and methyl bromide are some of the integrated disease control methods for Fusarium wilt of tomato (Ajilogba et al., 2013).

IDM is not a cure all control of plant diseases. It is a ecological method to balance plant health by minimizing loss cause by disease, the use of tactics that will differ according to the presence of a variety factors that modify disease development (Kendrick, 1988)

\section{Management of Fusarium wilt disease}

Fusarium wilt usually monocyclic demonstrate plant-to-plant dissemination during the season this is primary since there are no propulses capable of distributing to another plant to induce secondary infection forming over the field very late in the season there are some data indicating that Fusarium wilt, for example, Fusarium wilt of tomato may be a polycyclic disease capable of displaying secondary spread (Egel and martyn, 2007).

According to Borrero et al., (2006), Elmer 2006) and Hardion et al., 2001). It is difficult to manage Fusarium Wilt. some are initial methods of management, including cultural management, physical and chemical management. 


\section{Culture management}

Culture management provides strategies for controlling and planting that can measure the nature and volume of yield and thereby reduce the risk of pests and diseases. Changes in the ecosystem are often considered of nonmechanical means of managing plant pests and diseases. It is also provided an unfavourable atmosphere for the development of disease pathogens and pests (Islam 2001). It is also a useful manipulation of the crop in developing and growing plants to control plant diseases, insect damage and pests (Neshev, 2008) .Some developing countries using clean seed and long crop rotations are not practice solutions to the problem of tomato caused by Fusarium oxysporum inter cropping has been used because of reducing soil population of the pathogen and root to root transmission this indicate lower incidence in tomato growing with bean inter cropping (Hayward, 1991).

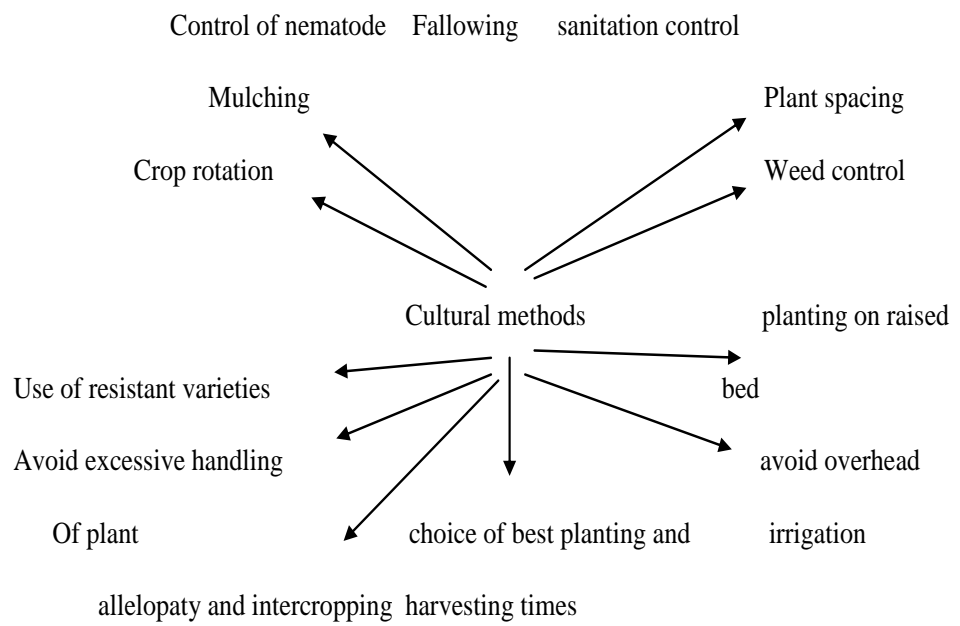

\section{Mulching}

Laying a dense layer of mulch to the soil surface helps to suppress weeds, to neutralise soil moisture and to keep soil cool. Mulching helps to create unfavourable conditions for soil born pathogens that control the disease (Raid, 2011). This method ignores splashing of soil born diseases on tomato leaves while watering (Francis, 2012).

\section{Sanitation}

Resting structures such as chlamydospores, microsclerotia and soil-borne plant pathogens can live a very long time in case absence of a living host or plant debris and soil organic matter. Sanitation includes any kind of operations aimed at avoiding the transmission of diseases by removing polluted plant parts, uncontaminated tools and equipment and clean hands. Weeds and undesired plants should be eliminated. Plowing under contaminated plant material to direct sunlight, which may kill some plant pathogens (BaysalGurel Gardener 2019).

\section{Plant parasitic nematode}

It can significantly restrict the benefit of the breed-specific tolerance to interacting fungi and increasing the severity of Fusarium wilt in susceptible cultivars (Castillo and NavasCortés, 2003). Also Fusarium wilt is one of the serious diseases of cotton, severity is high presence of root knot nematode Meloidogyne incognata and the nature of interaction between fungus and nematode is influenced 
by population level of two pathogens (De Vay et al., 1997).

\section{Varieties of resistance and grafting}

one of the most important method for disease control is the use of resistant varieties. As well as te production of resistant varieties through plant breeding, there is a timeconsuming attempt to balance resistance and choice for market quality (Katan, J. Plant Pathol 2017). There is no one plant variety that is resistant to all diseases. Varieties labelled with disease resistance have a higher degree of resistant to all diseases. Varieties labelled with disease resistance have a higher degree of resistance than those branded wilt tolerance (Baysal-Gurel, F., Gardener, 2019) regulation of soil diseases in tomatoes such as Fusarium oxysporum f.sp.lycopersici, Pyrenochaeta lycopersici, Fusarium oxysporum f.sp. radicis-lycopersici and Meloidogyne spp. have been successful in the use of resistance rootstocks in grafted plants (Mihajlovi'c, Rekanovi'2017).

\section{Allelopathy and inter cropping}

Allelopathy is a natural chemical reaction between plants. Some plants may develop toxic decomposed plant tissue with the aid of toxins produced by micro organisms, often the non- toxic material may be modified by microbial activity as a toxic substance. For example, the production of winter annual weeds may be confined to black walnut trees and Johnson grass often somehow regulates root knot nematodes (Wolfswinkel, 2010).

Intercropping: To plant two or more crops together in the same area at the same time. It helps to maintain the development of crops, soil fertility and reduce the prevalence of pests and diseases. For example. It is possible to intercrop tomatoes and maize so that the tomato gets shade from maize and is grown out of season, increasing the farmer's income yield (Wolfswinkel, 2010).

\section{Biological management}

Biological control is pollution free and most considerable method used to control Fusarium oxysporum (Anjajah et al., 2003). Plant growth promoting rhizobacteria (PGPR) may be effectively utilized as control agents for the wilt pathogen (Schmidt et al., 2004). Pseudomonas and bacillus (PGPR strains) may be exploited for root inhibiting pathogen (Joseph et al., 2007). Landa et al., (1997) reported that bacillus and pseudomonas can be used for chickpea wilt. These rhizobacteria produces pyrolnintrin, phenazin, phloroglucinol, siderophores that show and decrease the Fusarium oxysporum (Fridlender et al., 1993). Wani et al., (2007) and Verma et al., (2014) reported that bacillus, pseudomonas, trichoderma and burkholderia show most efficient bio-control agents for chickpea wilt. Trichoderma harzianum and bacillus subtillis show and decrease the disease by increasing $\beta$-1, 3 -glucanase enzyme activity and effectively decreasing the pathogen growth (Anjajah et al., 2003 and Moradi et al., (2012).

Chemical method: agricultural chemicals are commonly used for the control of pests and diseases. Seed treatment with industrial fungicides greatly decreases wilt disease. Perpetually their use is both expensive and environmentally unacceptable (Songandgoodman, 2001). Any of these compounds, such as prochloraz, ptopiconazole, thiabendazole, carbendazium, benomyl, fuberidazole, thiophante and all benzimidazole. (Nel et al., in 2007) benomyl has been reported to be partially successful against Fusarium oxysporum f.sp cubense using the root dip treatment process. This approach is extended to the use of Carbendazium in tomato seedlings 
contaminated with Fusarium wilt and can raise yield by up to 24 percent $(2007$, Net et al). various synthetic chemicals have been found effective for management of Fusarium wilt. Treat the seeds with Benlate with $30 \%$ thiram and $30 \%$ benomyl is helpful for managing the seed borne pathogens (Haware et al., 1978 and Pande et al., 2007). Chemichal control of soil born plant pathogens is commonly selected in wider crop production areas due to comparatively quick effects and easy action. Products in the dicarboximide, benzimidazole and trizole fungicide groups are known to control some of soil borne fungal diseases powerfully. (Budge and Whipps, 2001) (Matheron and Porchas, 2004). Treatment of soil with broadspectrum fumigants such as methyl bromide, chloropicrin or methyl isothiocyanate on its own or in mixtures successfully regulated Fusarium wilt of tomato and improved crop yield(K Beckman, C.H. 1987) However, soil fumigation efficiency is reduced either by the persistence of pathogen in soil layers below the depth of successful fumigation or by the reintroduction of pathogens by contaminated planting material or by conidia in the air or by irrigation water (Katan and Shlevin, 1997; Shokes and Mccaeter, 1979). Plant pathogens are widely selected in broader areas of crop production due to relatively fast results and simple intervention. Products in the dicarboximide, benzimidazole and trizole fungicide classes are known to control potently certain soil-borne fungal disease (Budge and Whipps, 2001; Matheron and Porchas, 2004).

In conclusion, a part from looking at the fact that these approaches operate in various ways, attempts should be made to analyse and improve their feasibility, usefulness and longetivity in the field. Separate formulations of microbial products which will provide the most effective outcome should also be considered to be very necessary for biological control purposes. The field of focus should then be to teach farmer about the effective use of cultural traditions and their incorporation into other methods for a greater and safe outcome.

\section{References}

Ajilogba, Caroline F., and Olubukola O. Babalola. Integrated management strategies for tomato Fusarium wilt. Biocontrol science 18, no. 3(2013): 117-127.

Anjaiah, V., Cornelis, P. and Koedam, N., 2003. Effect of genotype and root colonization in biological control of fusarium wilts in pigeonpea and chickpea by Pseudomonas aeruginosa PNA1. Canadian Journal of Microbiology, 49(2), pp.85-91.

Baysal-Gurel F, Kabir N. Comparative performance of fungicides and biocontrol products in suppression of Rhizoctonia root rot in viburnum. J Plant Pathol Microbiol. 2018; 9(451): 2.

Bawa, I. "Management strategies of Fusarium wilt disease of tomato incited by Fusarium oxysporum f. sp. lycopersici(Sacc.) A Review. Int. J. Adv. Acad. Res 2.5 (2016). orrietnam,pp. 126-133, ACIAR, Canberra. Beckman, Carl $\mathrm{H}$. The nature of wilt diseases of plants. APS press, 1987.

Bhatnagar, K., Tak, S. K., Sharma, R. S., Majumdar, V. L., and Meena, R. L. (2013). Management of cumin wilt caused by Fusarium oxysporum f. sp. cumini through chemical and biological agents. Indian Phytopathol, 66, 101-102.

Bishop, C. D., and Cooper, R. M. (1983). An ultrastructural study of vascular colonization in three vascular wilt diseases I. Colonization of susceptible 
cultivars. Physiological Plant Pathology, 23(3), 323-343.

Budge, Simon P., and John M. Whipps. "Potential for integrated control of Sclerotinia sclerotiorum in glasshouse lettuce using Coniothyrium minitans and reduced fungicide application." Phytopathology 91.2 (2001): 221-227.

Burgess LW, Phan HT, Knight TE, Tesoriero L. Diagnostic manual for plant diseases in Vietnam. Australian Centre for International Agricultural Research, ACIAR; 2008.

Charoenporn, C., Kanokmedhakul, S., Lin, F.C., Poeaim, S. and Soytong, K., 2010. Evaluation of bio-agent formulations to control Fusarium wilt of tomato. African Journal of Biotechnology, 9(36).

Castillo, Pablo, Juan A. Navas-Cortés, David Gomar-Tinoco, Mauro Di Vito, and Rafael M. Jiménez-Díaz. "Interactions between Meloidogyne artiellia, the cereal and legume root-knot nematode, and Fusarium oxysporum f. sp. ciceris race 5 in chickpea." Phytopathology 93, no. 12 (2003): 1513-1523.

DeVay, J. E., A. P. Gutierrez, G. S. Pullman, R. J. Wakeman, R. H. Garber, D. P. Jeffers, S. N. Smith, P. B. Goodell, and P. A. Roberts. "Inoculum densities of Fusarium oxysporum f. sp. vasinfectum and Meloidogyne incognita in relation to the development of Fusarium wilt and the phenology of cotton plants (Gossypium hirsutum)." Phytopathology 87, no. 3 (1997): 341346.

Egel DS, Martyn RD. Fusarium wilt of watermelon and other cucurbits. The Plant Health Instructor. DOI: 10.1094. PHI-I-2007-0122-01; 2007.

Elmer, Wade H. "Effects of acibenzolar-Smethyl on the suppression of Fusarium wilt of cyclamen." Crop Protection 25, no. 7 (2006): 671-676.

Fridlender, M., J. Inbar, and I. Chet. Biological control of soilborne plant pathogens by a $\beta-1,3$ glucanaseproducing Pseudomonas cepacia. Soil Biology and Biochemistry 25.9 (1993): 1211-1221.

Giovannucci E (1999) Tomatoes, tomatobased products, lycopene andcancer: Review of the epidemiologic literature. J Natl Cancer Inst 91: 317-331

Gomes, S.M.D.T.P., Romano, E.D.B., Pignoni, E., Teixeira, M.Z., da Costa Vasconcelos, M.E. and Jos Ã $f Æ$ E, A., 2010. Effect of biotherapic of Alternaria solani on the early blight of tomato-plant and the in vitro development of the fungus. International Journal of High Dilution Research-ISSN 1982-6206, 9(33), pp.147-155.

Hayward AC. Biology and epidemiology of bacterial wilt caused by Pseudomonas solanacearum. Annual review of phytopathology. 1991; 29: 65-87.

Haware, M. P., Nene, Y. L., and Rajeshwari, R. (1978). Eradication of Fusarium oxysporum f. sp. ciceri transmitted in chickpea seed. Phytopathology, 68(9), 1364-1367.

Islam, Z. (2001). Control of rice insect pests.(Atkinson, A, D., ed.). International Rice Research Institute, Philippines, Pp. 4-20.

Jha, A. C. Integrated management of tomato wilt caused by Fusarium oxysporum f. sp. lycopersici. (2018).

Jeff, G., 2009. The importance of organic matter in soil fertility and crop health. organic broadcaster. The bi-monthly periodical of the mid-west organic sustainable education service, pp.715778.

Joseph B, Ranjan Patra R, Lawrence R. Characterization of plant growth promoting rhizobacteria associated 
with chickpea (Cicer arietinum L.). International Journal of Plant Production. 2012 Jul 24;1(2):141-52.

Katan T, Shlevin E, Katan J. Sporulation of Fusarium oxysporum f. sp. lycopersici on stem surfaces of tomato plants and aerial dissemination of inoculum. Phytopathology. 1997 Jul; 87(7): 7129.

Katan, J. "Diseases caused by soilborne pathogens: biology, management and challenges." Journal of Plant Pathology 99.2(2017): 305-315.

Keswani, Chetan. "Proteomic studies of thermotolerant strain of trichoderma spp." $\mathrm{PhD}$ diss., Banaras Hindu University, 2015.

Khan, M.R. and Khan, S.M., 2002. Effects of root-dip treatment with certain phosphate solubilizing microorganisms on the fusarial wilt of tomato. Bioresource technology, 85(2), pp.213-215.

Labrada, R. (2008). Alternatives to replace methyl bromide for soil-borne pest control in East and Central Europe. Manual. FAO/UNEP.

L'Haridon, Floriane, Sébastien Aimé, Sébastien Duplessis, Claude Alabouvette, Christian Steinberg, and Chantal Olivain. "Isolation of differentially expressed genes during interactions between tomato cells and a protective or a non-protective strain of Fusarium oxysporum." Physiological and molecular plant pathology 76, no. 1 (2011): 9-19.

Lewis, J. A., and G. C. Papavizas. "Biocontrol of cotton damping-off caused by Rhizoctonia solani in the field with formulations of Trichoderma spp. and Gliocladium virens." Crop protection 10.5 (1991): 396-402.

Lenucci, M.S., Cadinu, D., Taurino, M., Piro, G. and Dalessandro, G., 2006. Antioxidant composition in cherry and high-pigment tomato cultivars. Journal of agricultural and food chemistry, 54(7), pp.2606-2613.

Matheron, M. E., and M. Porchas. Activity of boscalid, fenhexamid, fluazinam, fludioxonil, and vinclozolin on growth of Sclerotinia minor and $S$. sclerotiorum and development of lettuce drop. Plant Disease 88, no. 6 (2004): 665-668.

Mendgen, Kurt, M. Hahn, and Holger Deising. Morphogenesis and mechanisms of penetration by plant pathogenic fungi. Annual review of phytopathology 34, no. 1 (1996): 367386.

Mihajlovi'c, M., Rekanovi'c, E., Hrusti'c, J., Tanovi'c, B. Methods for management of soilborne plant pathogens. Pestic. Fitomedicina 2017, 32, 9-24. [CrossRef]

Minuto, A.N.D.R.E.A., Gilardi, G., Gullino, M.L. and Garibaldi, A., 2000, September. Combination of soil solarization and dazomet against soilborne pathogens of glasshousegrown basil, tomato and lettuce. In International Symposium on Chemical and Non-Chemical Soil and Substrate Disinfectation 532 (pp. 165-170).

Mui-Yun, W. Fusarium oxysporum f. sp. lycopersici (Sacc.): PP728 Soil-borne Plant Pathogen Class Project." North Carolina State University (2003).

Mukhopadhyay AN. Biological control of soil borne plant pathogens by Trichoderma spp. Indian Journal of Mycology and Pathology. 1987; 17: 1-0.

Nel, B., Steinberg, C., Labuschagne, N., and Viljoen, A. (2007). Evaluation of fungicides and sterilants for potential application in the management of Fusarium wilt of banana. Crop Protection, 26(4), 697-705.

Naika, S., et al., "Cultivation of tomato production, processing and marketing, 
Agromisa/CTA." Revised edition, Agrodokseries 17 (2005).

Naika, S., J. Juede, M. Goffau, M. Hilmi, and V. Dam. "Cultivation of tomato production, processing and marketing, Agromisa/CTA." Revised edition, Agrodokseries 17 (2005).

Ortiz, Emiro, et al., Histopathological features of infections caused by Fusarium oxysporum and F. solani in purple passionfruit plants (Passiflora edulis Sims). Summa Phytopathologica 40.2 (2014): 134-140.

Panth, Milan, Samuel C. Hassler, and Fulya Baysal-Gurel. "Methods for Management of Soilborne Diseases in Crop Production." Agriculture 10, no. 1 (2020): 16.

Pande S, Rao JN, Sharma M. Establishment of the chickpea wilt pathogen Fusarium oxysporum f. sp. ciceris in the soil through seed transmission. Plant Pathology Journal. 2007;23(1):36.

Pythium damping-off by the antagonistic bacteria Pseudomonas fluorescens and Bacillus subtilis. Phytopathology 94, no. 4 (2004): 351-363.

Schmidt, C. S., F. Agostini, C. Leifert, K. Killham, and C. E. Mullins. "Influence of soil temperature and matric potential on sugar beet seedling colonization and suppression of

Song F, Goodman RM. 2001. Molecular biology of disease resistance in rice.
Physiological and Molecular Plant Pathology. 2001 Jul 1; 59(1):1-1.

Shokes, F. M., and McCarter, A. M. (1979). Occurrence, dissemination, and survival of plant pathogens in surface irrigation ponds in southern Georgia. Phytopathology, 69(5), 510-516.

Singh, R.S. (2014). Plant Diseases 9thedition. ISBN978-81-204-17465

Singh, Bhupendra Kumar, Vinit Pratap Singh, Seweta Srivastava, Abhay Kumar Pandey, and D. N. Shukla. "Influence of soil properties on wilt incidence of water melon, tomato and marigold." Annual Research and Review in Biology (2017): 1-6.

Unit, Recycled Organics. "Compost use for pest and disease suppression in NSW. Recycled Organics Unit. The Univ. of New South Wales, Australia." (2006).

Waiganjo, M. M., Wabule, N. M., Nyongesa, D., Kibaki, J. M., Onyango, I., Wepukhulu, S. B., and Muthoka, N. M. (2006). Tomato production in Kirinyaga district, Kenya, a baseline survey report. Kenya Agricultural Research Institute, Nairobi, Kenya, 143.

Wang, C. and Roberts, P.A., 2006. A Fusarium wilt resistance gene in Gossypium barbadense and its effect on root-knot nematode-wilt disease complex. Phytopathology, 96(7), pp.727-734.

\section{How to cite this article:}

Pothula Himabindu and Vipul Kumar. 2021. Methods for Management of Fusarium Wilt in Tomato. Int.J.Curr.Microbiol.App.Sci. 10(01): 363-371. doi: https://doi.org/10.20546/ijcmas.2021.1001.045 